Report Title:

\title{
Reforming of Liquid Hydrocarbons in a Novel Hydrogen-Selective Membrane-Based Fuel Processor
}

Report Type: Annual Technical Report

Reporting Period Start Date: 09/30/2001 End Date: 09/29/2002

Principal Author(s): Shamsuddin Ilias

Report Issue Date: June 30, 2003 DOE Award No.: DE-FG26-01NT41361

Name and Address of Submitting Organization:

North Carolina A\&T State University

Department of Chemical Engineering

Greensboro, NC 27411

E-mail: ilias@ncat.edu

Tel: (336) 334-7564 Fax: (336) 334-7904 


\section{DISCLAIMER}

This report was prepared as an account of work sponsored by an agency of the United States Government. Neither the United States Government nor any agency thereof, nor any of their employees, makes any warranty, express or implied, or assumes any legal liability or responsibility for the accuracy, completeness, or usefulness of any information, apparatus, product, or process disclosed, or represents that its use would not infringe privately owned rights. Reference herein to any specific commercial product, process, or service by trade name, trademark, manufacturer, or otherwise does not necessarily constitute or imply its endorsement, recommendation, or favoring by the United States Government or any agency thereof. The views and opinions of authors expressed herein do not necessarily state or reflect those of the United States Government or any agency thereof. 


\begin{abstract}
We propose to develop an inorganic metal-metal composite membrane to study reforming of liquid hydrocarbons and methanol by equilibrium shift in membrane-reactor configuration, viewed as fuel processor. Based on our current understanding and experience in the Pd-ceramic composite membrane, we propose to further develop this membrane to a Pd and Pd-Ag alloy membrane on microporous stainless steel support to provide structural reliability from distortion due to thermal cycling. Because of the metal-metal composite structure, we believe that the associated end-seal problem in the Pd-ceramic composite membrane in tubular configuration would not be an issue at all. We plan to test this membrane as membrane-reactorseparator for reforming liquid hydrocarbons and methanol for simultaneous production and separation of high-purity hydrogen for PEM fuel cell applications.

To improve the robustness of the membrane film and deep penetration into the pores, we have used osmotic pressure field in the electroless plating process. Using this novel method, we deposited thin Pd-film on the inside of microporous stainless steel tube and the deposited film appears to robust and defect free. Work is in progress to evaluate the hydrogen perm-selectivity of the Pd-stainless steel membrane.
\end{abstract}




\section{TABLE OF CONTENTS}

Title page $\quad$ i

Disclaimer $\quad$ ii

$\begin{array}{ll}\text { Abstract } & \text { iii }\end{array}$

Table of Contents

Executive Summary $\quad$ V

$\begin{array}{ll}\text { Introduction } & 1\end{array}$

Research Objectives 1

Experimental: Materials and Methods $\quad 2$

$\begin{array}{ll}\text { Results and Discussion } & 4\end{array}$

$\begin{array}{ll}\text { Conclusions } & 5\end{array}$

$\begin{array}{ll}\text { References } & 5\end{array}$ 


\section{EXECUTIVE SUMMARY}

To develop, defect free hydrogen-selective metal-metal composite membrane, we have osmotic pressure field induced electroless plating to deposit Pd-film on microporous stainless steel tube. The new membrane appears to robust and defect free. The ultimate objective of this work is to use this new membrane in membrane-reactor-separator configuration for reforming of liquid hydrocarbons and methanol for production and separation of high purity hydrogen for fuel cell application. Work is in progress to characterize the membrane for hydrogen permeability and selectivity. 


\section{INTRODUCTION}

A fuel processor is a major subsystem in fuel cell power system. Fuel processing depends on both the raw fuel and the fuel cell technology. The fuel cell technology determines what constituents are desirable and acceptable in the processed fuel. Since gaseous hydrogen (nearly pure) is considered as the fuel of choice in all fuel cells, hydrogen needs to be generated from other fuels and processed to meet various system requirements [1,2]. From economical and practical considerations, hydrocarbon reforming and hydrogen purification processes for an integrated fuel cell system need to meet several key criteria: (i) produce high-purity hydrogen, (ii) modular compact unit in size and weight, (iii) have low parasitic power requirements, (iv) be economic, affordable, and (v) exhibit rapid-load-following capability. To meet these requirements, we proposed membrane-based technology for hydrocarbon reforming and hydrogen separation.

Inorganic membrane reactors offer the possibility of combining reaction and separation in a single operation at high temperatures to overcome the equilibrium limitations experienced in conventional reactor configurations. Such attractive features can be advantageously utilized in a number of potential commercial opportunities, which include dehydrogenation, hydrogenation, oxidative dehydrogenation, oxidation and catalytic decomposition reactions. However, to be cost effective, significant technological advances and improvements will be required to solve several key issues which include: (a) permselective thin solid film, (b) thermal, chemical and mechanical stability of the film at high temperatures, and (c) reactor engineering and module development in relation to the development of effective seals at high temperature and high pressure.

In the proposed research, we will focus on the development and application of palladium thin-film composite membrane in a membrane reactor-separator configuration for separation of hydrogen at high temperature. From our current research on Pd-composite membrane, we have demonstrated that the new membrane has a significantly higher hydrogen flux with very high perm-selectivity than any of the membranes commercially available.

Currently, the major focus on PEMFC technology is to develop fuel cell system for transportation applications, which require development of low cost cell components. The PEMFC technology is attractive because of its low operating temperature and ease of start-up. Reformed methanol is expected to be major fuel source in PEMFCs for terrestrial transportation application. The poisoning of the expensive electrocatalysts by $\mathrm{CO}$ in the reformed fuel is a major concern. Crossover of methanol in direct methanol PEMFC is also problematic [1,3]. Thus, there is a need for developing technology for reforming methanol and liquid hydrocarbons as a source of hydrogen to the fuels cells. In this context, membrane-based technology as fuel processor appears very attractive.

\section{RESEARCH OJECTIVES}

The objectives of this research are to:

1. Design and fabrication of membrane reactor using thin film $\mathrm{Pd}$ and $\mathrm{Pd}-\mathrm{Ag}$ alloy composite membrane in tubular configuration on porous stainless steel substrate.

2. Conduct steam reforming of methanol experiments to study the equilibrium shifts and permeation characteristics. 
3. Model the membrane reactor for methanol reforming by equilibrium shift and validate the performance of the reactor.

\section{EXPERIMENTAL: MATERIALS \& METHODS}

The objectives of this research are to fabricate dense, thin-film Pd membrane on microporous stainless steel substrate in tubular configuration, suitable for high temperature reactions, and to use this membrane as membrane reactor-separator for hydrogen separation in a steam reforming of methane reaction. Development of this type of membrane involves plating of the substrate, hydrogen permeability tests, and performing the reaction.

\section{Electroless Plating of Pd on Microporous Substrates}

To develop a new class of $\mathrm{H}_{2}$-selective inorganic membrane, in our lab we have used electroless plating to deposit a palladium thin-film on microporous ceramic substrate [3, 4]. Electroless plating is a controlled autocatalytic deposition of a continuous film on the surface of a substrate by the interaction of a metal salt and a chemical reducing agent. In this work, we used microporous stainless steel discs and tubes to deposit Pd-film to prepare the hydrogen-selective Pd-composite membranes.

Electroless plating is a three steps process, which include substrate cleaning, sensitization and activation, and electroless plating. The basic principles of electroless plating are well established and may be found elsewhere [3-5]. For brevity, details are not repeated here.

Pretreatment of the Substrate: Stainless steel substrate was cleaned by commercial cleaner followed by cleaning with analytical grade carbon tetrachloride. The cleaning was done to remove any organisms, residual metals and dust. The cleaning step is vital to ensure that activation and plating take place across the exposed surface and into the pores of the substrate.

Sensitization and Activation: The compositions for sensitization and activation solution are listed in Table 1. For discs, one face and the edges were wrapped with Teflon tape to prevent sensitization and activation. For tubes, the outer sides of the tubes were wrapped with Teflon tapes. They were dipped successively in acidic $\mathrm{SnCl}_{2}$ solution followed by acidic $\mathrm{PdCl}_{2}$ solution at room temperature. Each dip lasted for about 4 to 5 minutes and was followed by washing with distilled water for about one minute between each dip. They were dipped in the $\mathrm{SnCl}_{2}$ and $\mathrm{PdCl}_{2}$ solutions alternately for several times to ensure sensitization and activation of the substrate for electroless plating.

Table 1. Composition of Sensitization and Activation Solutions

\begin{tabular}{|l|l|l|}
\hline & Activation & Sensitization \\
\hline Solute & $\mathrm{PdCl}_{2}$ & $\mathrm{SnCl}_{2}$ \\
\hline Solute Concentration & $0.09 \mathrm{~g} / \mathrm{L}$ & $1.19 \mathrm{~g} / \mathrm{L}$ \\
\hline Solvent & $0.2 \mathrm{~N} \mathrm{HCl}$ & $0.2 \mathrm{~N} \mathrm{HCl}$ \\
\hline Temperature & $25^{\circ} \mathrm{C}$ & $25^{\circ} \mathrm{C}$ \\
\hline
\end{tabular}


Electroless plating: The activated discs and tubes were wrapped with fresh tape, and then put in the electroless plating solution for an hour. The plating step was continued until a dense membrane was made. Each time the substrate was dipped into the fresh plating solution. Then they were dried in oven at $80{ }^{\circ} \mathrm{C}$ for 1 hour. The recipe used for electroless plating is given in Table 2.

Table 2. Composition of Palladium Electroless Plating Bath Solution

\begin{tabular}{|l|l|}
\hline Component & Concentration \\
\hline EDTA & $40 \mathrm{~g} / 1$ \\
\hline Ammonium Hydroxide (5N) & $600 \mathrm{ml} / 1$ \\
\hline $\mathrm{PdCl}_{2}$ & $40 \mathrm{~g} / 1$ \\
\hline $\mathrm{N}_{2} \mathrm{H}_{4}(1 \mathrm{M}$ solution) & $10 \mathrm{ml} / 1$ \\
\hline $\mathrm{PH}$ & 11 \\
\hline Temperature & $45^{\circ} \mathrm{C}$ \\
\hline
\end{tabular}

After plating stainless steel discs, we found from the EDX results that palladium is more difficult to be plated on stainless steel substrate than on alumina substrate. It seems that metals atoms $(\mathrm{Pd})$ are not firmly bonded to stainless steel substrate. To overcome this limitation, a modified electroless plating method then was used [6]. It used osmotic pressure as the driving force to make the solvent of the plating solution get into the tiny holes (pores) of the substrate to help plate palladium onto the wall of the holes, then block them with the growth of the palladium film. Secondly, osmotic pressure would press palladium onto the substrate to make the membrane compact and robust. We used poly ethylene glycol (30\%) for higher osmotic pressure.

The modified electroless plating process is shown schematically in Figure 1. The plating equipment includes a pump, the plating solution and a water bath. The metal film is deposited on the inside wall of the tubular substrate. By this modified electroless plating method, we were able to obtain stable Pd film on microporous substrate.

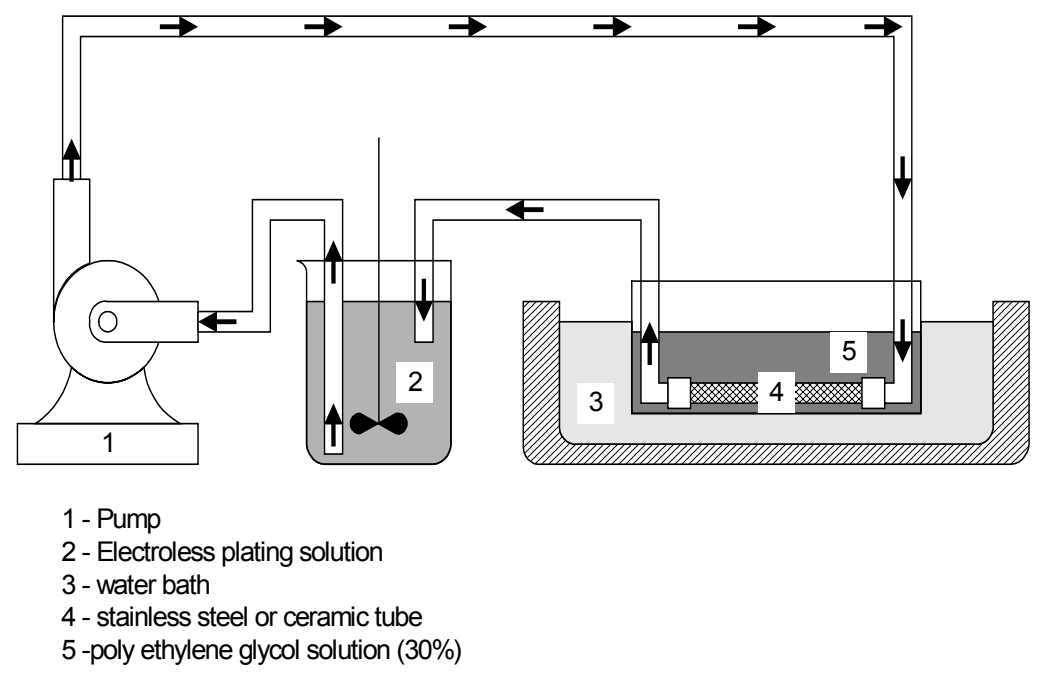

Figure 1: Experimental Setup for Electroless Plating with Osmotic Pressure Field 


\section{RESULTS AND DISCUSSIONS}

\section{Composite Membrane Characterization}

Scanning Electron Microscopy (SEM) and Energy Dispersive Xray (EDX) were used to analyze the substrates and Pd-membrane films. SEM shows the morphology of membrane, while EDX reveals the elemental composition of the surface or film. In Figure 1, typical SEM of the membrane surface and cross-sectional views of the tube with deep penetration of the $\mathrm{Pd}$ into the pore structures are shown. In Figure 2, the same cross section is shown by illumination to show the pores filled with $\mathrm{Pd}$.

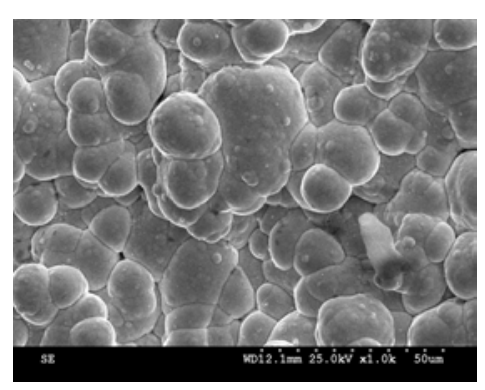

(a) Surface

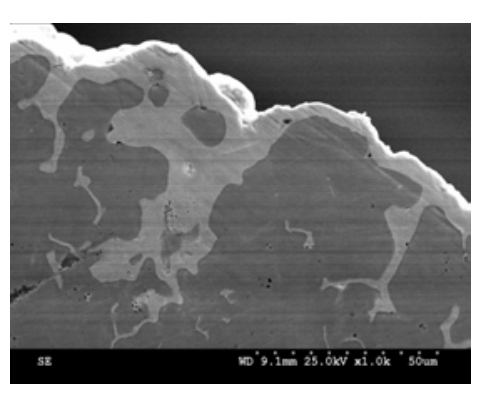

(b) Cross section

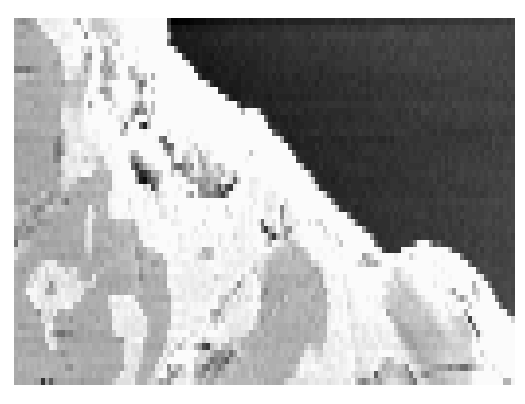

(c) Cross section at different angle

Figure 1: SEM of Pd-Stainless steel membrane. (a) Pd-film on stainless steel surface, (b) crosssectional view of the tube surface, and (c) cross-sectional view at a different angle showing deep penetration of $\mathrm{Pd}$ into the pore structures.

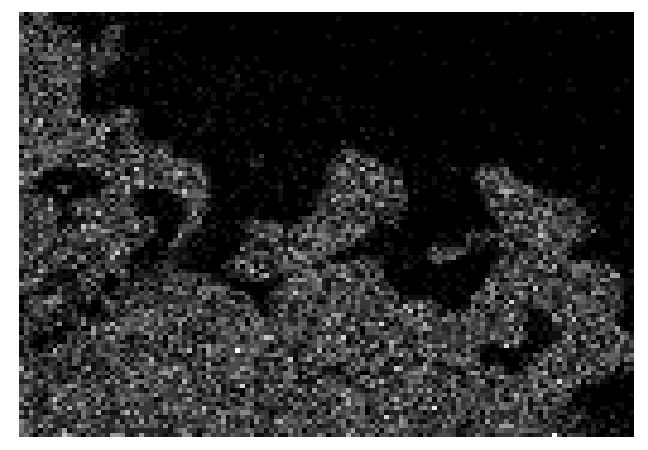

(a) Stainless steel (gray color)

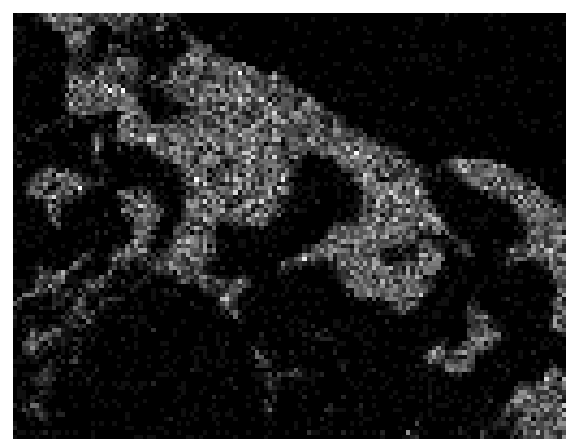

(b) Deposited Pd (white color)

Figure 2: SEM of illuminated cross-section of Pd-stainless steel tube. (a) Stainless steel (gray color), and (b) Deposited Pd (white color).

It appears that the osmotic pressure field induced electroless plating is capable of providing deep penetration of target metals into the pore and provides a defect free thin film. Work is in progress to evaluate the perm-selectivity of hydrogen of the Pd-stainless membrane. In our next report, we 
will provide an update on this and our planned work on membrane reactor for reforming liquid hydrocarbons using this new membrane.

\section{CONCLUSIONS}

To overcome the limitations of conventional electroless plating to deposit thin metal film in porous substrate, we have used osmotic pressure field to induce deep penetration of target metal into pore structures. Using this novel method, we deposited thin Pd-film on the inside of microporous stainless steel tube and the deposited film appears to robust and defect free. Work is in progress to evaluate the hydrogen perm-selectivity of the Pd-stainless steel membrane.

\section{REFERENCES}

1. Hirschenhofer, J.H., Stauffer, D.B., Engleman, R.R., and Kjlett, M.G., Fuel Cell Handbook, $4^{\text {th }}$ edition, U.S. DOE, Oak Ridge, Tennessee (1999).

2. Shu, J., et. al., "Catalytic Palladium-based Membrane Reactors: A Review," CJChE., 69, 1036 (1991).

3. Collins, J.P., and Way, J.D., "Preparation and Characterization of a Composite PalladiumCeramic Membrane," Ind. Eng. Chem. Res., 32, 3006-3013 (1993).

4. Ilias, S., Su, King, F.G., N., and Udo-Aka, U.I.,"Application of Electroless Deposited Thinfilm Palladium Composite Membrane in Hydrogen Separation," Sep. Sci. \& Tech., 32(1-4), 487 (1997).

5. Uemiya, S., et. al., "Separation of Hydrogen Through Palladium Thin-film Supported on a Porous Glass Tube," J. Memb. Sci., 56, 303 (1991).

6. Yeung, K.L., and Varma, A., "Novel Preparation Techniques for Thin Metal-Ceramic Composite Membranes," AIChE J., 41, 2131 (1995). 